\title{
Politics of Equivocation and Deferral: Queen Elizabeth I and the Execution of Queen Mary of Scotland
}

\author{
Nabanita Chakraborty \\ Assistant Professor, Hansraj College, University of Delhi. orcid.org/oooo-ooo1-7182-6246. \\ Email: cnita.in@gmail.com
}

Received October 29, 2016; Revised December 21, 2016; Accepted December 25, 2016; Published January 14, 2017

\begin{abstract}
Equivocation, indecisiveness and delay in action have often been viewed pejoratively in a world dominated by the discourse of rationality, dynamic individual action and potentiality. My article argues that procrastination and equivocation can be political strategies to avoid exigencies in the state. To elaborate my argument, a speech of Queen Elizabeth I deferring the execution of Mary, Queen of Scots, November 24, 1586 has been closely analyzed to examine how rhetoric of ambiguity and deferral act as diplomatic and prudent approaches to promote peace and respond to political exigency in early-modern England. This article concludes that Queen Elizabeth's political statesmanship lies in understanding the dynamics of power related to voluntary inaction rather than to violent action.
\end{abstract}

Keywords: deferral, equivocation, politics, Queen Elizabeth I, Queen Mary of Scotland

\section{Introduction}

This article attempts to study Queen Elizabeth I of early-modern England and her calculated rhetorical approach to political crisis in the first part of her reign. It examines the rhetoric of equivocation, ambivalence and procrastination which have in effect both locutionary and illocutionary forces ${ }^{1}$ of utterance. This paper argues that Queen Elizabeth used defensive rhetorical strategies of ambiguity and deferral rather than aggressive and expansionist rhetoric to deal with foreign powers in the period 1568-1586. The methodology involves a historical case study of a particular exigency in Elizabethan regime and the queen's rhetorical speech as a response to the crisis. A critical engagement with the speech of Elizabeth elucidates an efficient political strategy of administration --- deferring action rather than undertaking decisive action at a time of crisis. Consequently, I wish to underline how rhetoric of ambiguity and deferral are strategies to avert danger and wait for the opportune moment to act.

\section{Political Rhetoric of Queen Elizabeth I}

Queen Elizabeth I ruled England singlehandedly for over four decades (1558-1603) amidst dynastic controversy, religious reformation, economic upheaval and threat of a foreign Catholic invasion. She employed the power of language (ingenious rhetorical tropes to persuade or conciliate) rather than the language of power (through force or assertion) to govern the English state. Yet historians

(c) AesthetixMS 2016. This Open Access article is published under a Creative Commons Attribution Non-Commercial 4.0 International License (http://creativecommons.org/licenses/by-nc/4.o/), which permits non-commercial re-use, distribution, and reproduction in any medium, provided the original work is properly cited. For citation use the DOI. For commercial re-use, please contact editor@rupkatha.com. 
have often criticized Queen Elizabeth for her cautious and irresolute attitude when dealing with foreign powers. Charles Wilson has been the most unforgiving critic of Queen Elizabeth as he observes that there was no such international policy of Elizabeth, rather it was:

in reality, a succession of shifts and muddles into which the Queen stumbled because she was so obsessed by understandable but irrational fears - the fear of rebellions, the fear of France especially - or the obverse of those fears- the deference towards Philip II, the desire to recover Calais? $?^{2}$

Elizabeth often procrastinated and delayed decisive action while key issues of foreign policy were decided by her able councilors like Francis Walsingham and William Cecil. However, it might be a reductive approach to identify Elizabeth's vacillating attitude as her weakness in administrative policy or fear in undertaking any action. It would be similarly limiting to view her apparent irrational vagaries as either characteristic of her lack of religious conviction or complete reliance upon her councilors. Arguably, equivocation as a political strategy is often a far-sighted and prudent approach to statesmanship where political choices, preferences or possibilities are kept open. The secret of Elizabeth's politics lies in understanding the dynamics of power related to voluntary inaction rather than to violent action. There is always a possibility of bad outcome that might materialize by deferring action but nonetheless it is a wise strategy to confuse one's rivals with one's unpredictability.

\title{
3. Anglo-Scottish Relations in Early Elizabethan Reign
}

\author{
"The daughter of debate \\ That discord aye doth sow \\ Shall reap no gain where former rule \\ Still peace hath taught to know. \\ No foreign banished wight \\ Shall anchor in this port: \\ Our realm brooks no seditious sects - \\ Let elsewhere resort."
}

(Queen Elizabeth, 'The Doubt of Future Foes, 1571)

The above quotation is a poem written by Elizabeth to express her fear and apprehension from her 'furture foes'. The Catholic Queen Mary of Scotland had been deposed from her throne and forced to flee from her Scottish rebels who accused her of murdering her husband Lord Darnley with the help of her alleged lover Bothwell. Mary, Queen of Scotts, also known as Mary Stuart was a cousin and an unbidden guest at the court of Elizabeth from 1568 to 1587, after which she was put on trial and executed ${ }^{4}$. The Scottish queen was also the next heir to the English throne and posed a threat to the personal self of Elizabeth as well as to her Protestant subjects. She attempted several treasons against Elizabeth during her stay in England and Elizabeth's councillors demanded her execution. Elizabeth was determined not to tolerate any act of sedition or treason in her land. Yet she delayed all legal proceedings against her cousin and refrained from making any public indictment against her accused cousin Mary. Elizabeth was afraid of a joint Catholic crusade against England led by France and the Popish Church if she executed Queen Mary. Moreover, she did not wish to authorize an act of regicide on her land by which the sacrosanct position of the monarch was challenged.

Queen Elizabeth's second reply to the Parliamentary Petition urging the execution of Mary, Queen of Scots, November 24, 1586 is a speech act at a moment of crisis for the English 
queen and her realm. This speech by Elizabeth pre-empts the execution of Mary, Queen of Scots which ultimately did take place on February 8, 1587 (almost three months after this speech). However, at the time when this speech is delivered, the decision of Elizabeth is important to pronounce Mary's guilt and order the latter's execution. Elizabeth's speech carries a tremendous potential of action or rather a quasi-military force in itself since the nation waits for one affirmative reply from the Tudor queen to unleash violence upon the convicted queen. This period of extreme unrest in Elizabeth's rule and her careful and strategic handling of the issue is a yardstick to measure her competence as a political ruler. This paper deals with such an example of her political maneuvering at a time of vulnerability and crisis both to her private and public self. ${ }^{5}$

\subsection{Queen Elizabeth's Speech in the Parliament on November 24, 1586}

"Then her majesty turned to the lords and said that she never had a greater strife within herself than she had that day, whether she should speak or be silent, lest if she should speak, in showing her affection, she might seem to dissemble, and if she should be silent she might do them wrong in not answering their expectations. And then with a low voice she spake unto them of the complaint, which afterwards she spake unto the Commons as ensueth:

I perceive you have well considered my last message sent unto you, proceeding from an earnest desire and a hungry will in me that some way might be by you for my safety devised without the execution of that Act whereunto by your petition I was moved. But nothing being found for my satisfaction in that behalf, I must needs make a great complaint, not of you for I make it unto you, nor of myself but of my case which at this present is such, by reason of the many practices against me and the great mischief intended towards me, that now the bane of the injurer must be the only cure of my danger. Whereof to think it grieveth me not a little, considering that there be some which will not stick to shed their own blood for the sake and defense of their kin, and that by me it should be said hereafter, a maiden queen hath been the death of a prince, her kinswoman. A thing in no sort deserved by me, howsoever by the despite of malice it may be reported of me.

I have cause to think how narrowly mine actions are like to be sifted and finely scanned by some good fellows abroad, who spare not to publish pamphlets, libels, and books against me with detestation of me and my government...such rebels there are beyond the seas; I hope there are no such within the realm, I pray God there be not, but I will not swear it. But to clear myself of that fault, this I may justly say: I have pardoned many traitors and rebels, and besides I well remember half a score treasons which have either covered or slightly examined or let slop and passed over, so that mine actions have not been such as should procure me the name of a tyrant. Yet this of myself must I needs confess: though for that crime I am not justly to be touched, I am a wretched sinner and humbly desire pardon at His hands against whom I have offended for the same.

And now, as touching you, I must needs say and confess that there was never prince more bound to his people than I am to you all. I can but acknowledge your great love and exceeding care of me to be such as I shall never be able to requite, having but one life, except I had as many lives as you all. But I will never forget it while I shall breathe. And though I may want the means and the wit, yet surely I shall never want the will to requite it. 
But peradventure it may seem strange unto you that I should cherish a sword in mine own realm to shed mine own blood. I do not say I will do so. And yet I know there are many which venture their lives oftentimes for a less matter than the safety of a kingdom. And haply in this case I might adventure much more, were it with danger of mine own life, which I protest before God I chiefly regard in regard of yours.

But it seemeth most strange unto me that everyone, both of you, my lords, and the rest, should all agree in one that it should be a thing most hard, for me to live in safety without execution of your demand. And here I must say unto you, if any person be so wicked to think that the last message which I sent unto you was a thing done pro forma tantum and that I meant it not indeed, or that it proceeded from a vainglorious mind, as that I sought thereby the more to be commended for clemency and gentleness of nature, or that I meant to make the lords wire-drawers to draw the matter still into length without cause, he doth me greater wrong than ever he can be able to recompense. I did it, I protest before God, as being most desirous to understand every man's opinion whereby to perceive what was fittest for me to do, wherein my mind was that every one of my lords should frankly utter his conceit either publicly in the House or privately to myself, lest some of them, being suspected, might for that cause be silent.

But now for answer unto you, you must take an answer without answer at my hands. For if I should say I would not do it, I should peradventure say that which I did not think, and otherwise than it might be. If I should say I would do it, it were not fit in this place and at this time, although I did mean it. Wherefore I must desire you to hold yourselves satisfied with this answer answerless...there must be deeds and not words which must satisfice your demand. I pray you therefore, let this answer answerless content you for this present, assuring yourselves that I am now and ever will be most careful to do that which shall be best for your preservation. And be not too earnest to move me to do that which may tend to the loss of that which you are all most desirous to keep."

\subsection{Reading the Speech of Elizabeth}

Throughout the speech, Queen Elizabeth I neither mentions the person convicted (Queen Mary of Scots) nor the impending act (execution). The unspoken act (mentioned with a definitive pronoun 'that' and treated as a proper noun 'Act') seems to loom large upon everyone's mind since it is a monstrous act of regicide. The mention of the 'mischief intended' towards her is again an implicit reference to the threat the Scottish queen posed to her life, the safeguard of which was important for the continuation of the Protestant religion in the Church of England. I wish to underline the unspoken word and the unnamed act of regicide, the potential of which seems to carry more force than the act itself.

The queen, otherwise an excellent orator, consciously obfuscates the language: "I must needs make a great complaint, not of you for I make it unto you, nor of myself but of my case". The pronouns I and you are prominent here since they aim at "identification" but results in creating division. "Identification" for Kenneth Burke means something like empathy or association. Burke explains:

"You persuade a man only insofar as you can talk his language by speech, gesture, tonality, order, image, attitude, idea, identifying your ways with his". ${ }^{7}$ 
Identification means strategic alliances between groups, whose interests are opposed, to gain particular ends. However, the issue is complicated by Burke since identification also includes moments of self-persuasion which we are not conscious of. When individuals identify with one another, divisions still exist, although they are now hidden. Burke exposes structural and ideological "persuasions", an identification which acts to mystify the rhetorical "motive" concealed within it. Burke's theory becomes problematic when we see the orator consciously trying to build rapport and alienating herself from her audience at the same time. For Burke, the agency of the rhetor is minimized since identification sought or divisions created are most often unconscious acts within rhetorical practices.

The rhetoric of identification in this speech "I must needs make a great complaint, not of you for I make it unto you, nor of myself but of my case", besides, affecting a rapport shared by the queen with her council, also forges a bond through a shared sense of responsibility, exercised through the reciprocal act of dispensing and receiving counsel. While "consent" of the councilors was required in a mixed monarchy to prevent the royal authority from exercising tyrannical powers, it is ironically the queen's consent which is awaited here, to proceed with the trial of the accused queen of Scotland. In fact, the queen begins by accusing mildly her councilors for failing to provide her proper counsel: "But nothing being found for my satisfaction in that behalf, I must needs make a great complaint..." The reply of Queen Elizabeth is to respond to the demands of her parliament - "that some way might be by you for my safety devised without the execution of that Act". The queen's rhetoric is symptomatic of the dilemma she is faced with. Queen Elizabeth is caught in a double bind: to alleviate the threat posed by a Catholic queen to her throne and at the same time to exacerbate the threat to herself by challenging the ideology of God's elected. Her decision to execute would lead to conservation of her sovereign self while endangering her vulnerable natural self to rebellious individuals or factions.

Simultaneously, she had to ruthlessly dominate or contain any breach of allegiance or treason on the part of her cousin. This was the dilemma/ conflict that prevented her from applying the law of treason or rebellion against Queen Mary. It is to be noted that since her accession, Elizabethan parliament had modified some of the earlier acts and statutes of the land to protect her rightful claim to monarchy. As early as 1559, two acts were passed which clarified Elizabeth's claim to the throne and revived the treason act. ${ }^{8}$ The definition of treason was aimed against the supporters of the Roman Catholicism but it was also combined with acts to punish any defiant individual/individuals or factions. These laws were reinforced in the context of the rebellion of the northern earls, the papal bull excommunicating and deposing Queen Elizabeth and the intrigues of the Duke of Norfolk and Queen Mary of Scots. Christopher Brooks reminds us that treason trials were more common under Queen Elizabeth than the early Stuarts. ${ }^{9}$ Elizabethan court convicted the Duke of Norfolk (1571) and the Earl of Essex (1598) and Sir Walter Raleigh $^{10}(1603)$ on grounds of treason. From 1570 onward, Queen Elizabeth had grown intolerant and executed Catholic priests who refused to attend Anglican church services, John Stubbs was imprisoned and his right hand chopped off for writing a pamphlet opposing the proposed marriage of the queen to the French duke of Alencon. There is historical evidence of arresting, without trial, individuals who did not conform to the royal will namely William Fleetwood,

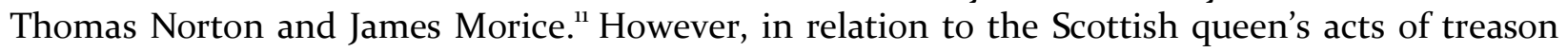
against Elizabeth's authority, the latter had to resort to manipulative and maneuvering strategies instead of direct recourse to law. ${ }^{12}$ The inconsistency between her speech and action is effective diplomatic rhetoric. Elizabeth's reference to traitors and rebels "I have pardoned many traitors and rebels..." contains contrary impulses: to be indifferent to hostilities and yet be wary of danger. 
The direct, effortless and explicit rhetoric of the legal statutes is opposed to the complex, painstaking and careful political rhetoric.

The rhetorical formulation required in this case would be deliberative rhetoric, the aim of which is to promote peace and goodness and avoid conflict/ war. However, Elizabeth, well trained in classical rhetoric, moves beyond the framework of deliberative rhetorical practice and displays "a shift from purposeful action to appropriate motivations". ${ }^{13}$ Instead of persuading her audience of her argument and seeking approval of her decision in a deliberative rhetoric, she deliberately places the onus of the decision on her parliamentarians, making herself inculpable of any act. In this case, a political choice or decision is subsumed within a wider system of social relations between the monarch and her parliamentarians.

In the next part of the speech, the queen deliberates upon another crisis threatening her: rebellious individuals, religious factions and supporters of the Scottish queen - her unnamed enemies within her own kingdom. Sir John Neale argued that 'puritanism' posed a coherent opposition to the Queen's policy in the first two parliaments of the reign. ${ }^{14}$ He identified a radical group which in 1559 forced a protestant settlement of the Church upon the Queen and some of the members formed a "choir" to produce libelous "pasquil" on the Queen. Neale's theory was challenged by G.R. Elton ${ }^{15}$, nonetheless, the queen's fear of rebellious religious groups, both Catholics and Puritans, was not unfounded. Her imminent danger was from her own hostile subjects whom she could not name but only implicate. Such contrary impulses get exploited through short antithetical sentences juxtaposed against each other, semantic tension of individual contrary thoughts resulting in a potential threat: "such rebels there are beyond the seas; I hope there are no such within the realm, I pray God there be not, but I will not swear it."

This is a shift from identification sought in the earlier part of the speech to a deliberate distancing from her subjects. We need to understand her fear of "rebels in this realm" since she was amidst both Catholic and Anglican subjects who were guided by individual self-interests. Elizabeth's predicament is expressed in her discordant and antithetical diction. Her incessant use of conjunctions to unite contradictory thoughts/impulses displays her anguish:

But peradventure it may seem strange unto you that I should cherish a sword in mine own realm to shed mine own blood. I do not say I will do so. And yet I know there are many which venture their lives oftentimes for a less matter than the safety of a kingdom.

The term 'haply' might possibly be 'happily' since at various points, the MS reads "happelie'. ${ }^{16}$ The term 'happily' signifies a positive declaration (assurance) of happiness in serving God and her nation. She claims that she is the chosen one of God thus legitimizing and justifying her power and position. It is evident from Elizabeth's speech that she was aware of the mixed responses of her audience given the fact that they consisted of both supporters as well as opponents of Queen Mary. A critical reading of Elizabeth's speech seems to reflect a kind of tacit agreement she shares with her audience, a consensual silence that permits her to hold back or procrastinate certain imminent truths - that of the execution of her cousin Queen Mary but more importantly Elizabeth's own vulnerability from the unnamed enemies.

"But it seemeth most strange unto me that everyone, both of you, my lords, and the rest, should all agree in one that it should be a thing most hard, for me to live in safety without execution of your demand..."

We need to note the phrase "the execution of your demand". The potential of the unsaid carries a lot of force which erupts suddenly, for example, the word or rather the deed of 'execution'. She was aware that word could sometimes be equivalent to action (we are not referring to Austin's 
theory of performative verbs in How To Do Things with Words.) Rather, this volcanic force breaks out through the faultlines of contrary impulses between deliberation/speech, potentiality/actuality. The unspoken energy appears through antithetical short sentences, pauses, breaks and conditionals:

And here I must say unto you, if any person be so wicked ... and that I meant it not indeed, or that it proceeded from a vainglorious mind, as that I sought thereby the more to be commended for clemency and gentleness of nature, or that I meant to make the lords wire-drawers...

The excessive use of conjunction 'or' is a strategy to be in a constant state of deferral where parliamentarians would be kept in a state of abeyance or a suspension between hope and fear. Elizabeth's speech displays diplomacy - her linguistic corpus is architectonically built up on a tension between ideal, normative, authoritative knowledge (that supports particular interests and ideologies of the dominant section of the society) and playfulness and slipperiness of expression (that is based on conditionality).In this way, Queen Elizabeth avoided criticism and maintained a diplomatic distance from her subjects.

She then ends with the ambiguous line: "Wherefore I must desire you to hold yourselves satisfied with this answer answerless". The ambiguity in the term "answer answerless" indicates Elizabeth's discrepancy between action and word. Elizabeth's rhetoric occupies a liminal space of possibility and actuality, word and deed. It suffices to say that her speech contains a quasimilitary force, a supplement to action which enables her to retain power. Her speech does not function to persuade the parliament; it transfers the onus of the monstrous act on her subjects. Her delaying strategy was aimed to prevent any military attack from the Catholic world in case the Catholic Scottish queen was executed.

\section{Conclusion}

Queen Elizabeth has often been criticized for her habitual vacillation and procrastination in her statesmanship where her action has not matched her speech. Her purposeless vagaries and indecisiveness are often viewed as her weakness of will. ${ }^{17}$ The queen's own ministers could not comprehend her varying moods and deferral tactics. In this article, I have argued that Elizabeth's vacillation did not involve irresolution (only rarely) or weakness of will. Elizabeth's dilatory strategy was a deliberate political ploy to deal with her foreign rivals.

\section{Notes}

\footnotetext{
${ }^{1}$ J.L. Austen's speech act theory in How to Do Things with Words defines locutionary as actual utterance consisting of semantic and syntactic meaning; illocutionary acts as an intended meaning such as promise or caution.

${ }^{2}$ Charles Wilson, Queen Elizabeth and the Revolt of the Netherlands, p 6.

3 This poem is thought to be written by Queen Elizabeth in response to the threat posed by the Catholic Queen Mary's flight into Protestant England in 1568 and her instigated Northern Rebellion, Elizabeth: Collected Works.
} 
${ }^{4}$ When Catholic Queen Mary was implicated with treason against Elizabeth, the councilors of Elizabeth demanded Mary's execution. Queen Mary had earlier fled from her own rebellious subjects of Scotland for allegedly involved in the murder of her husband.

${ }^{5}$ Ernst H. Kantorowicz in The King's Two Bodies explores the theory of the king as 'Corporation sole'..

6. Elizabeth I: Collected Works, p 196

${ }^{7}$ Kenneth Burke, A Rhetoric of Motives, p 55.

${ }^{8}$ D. Alan Orr in Treason and the State has a detailed analysis of treason in the English state.

9 Christopher W. Brooks, Law, Politics and Society in Early Modern England .

${ }^{10}$ Walter Raleigh was not put to death.

${ }^{11}$ The Execution of Justice in England by William Cecil; A True, Sincere, and Modest Defense of English Catholics by William Allen ed. R.M. Kingdon .

${ }^{12}$ Prof. Baker argues that treason and sedition were not dealt elaborately in professional law books evidently because the technicalities of treason were unfit for discussion. Yet while the judges showed considerable independence in the preliminary rulings in highly charged cases, they did cooperate with the law officers in drafting indictments (Dyer's Reports, ed. J.H.Baker, I, p. lxiii).

${ }^{13}$ Susan Miller, Trust in Texts.

${ }^{14}$ Sir John Neale, Queen Elizabeth I and her Parliaments

${ }^{15}$ G.R. Elton, The Parliament of England 1559-1581

${ }^{16}$ The Preface in Queen Elizabeth I: Collected Works informs us that texts of speeches bearing the mark of Elizabeth's hand sometimes circulated as official versions that had been reshaped after oral delivery for the purpose of dissemination to a broader public.

${ }^{17}$ J.A. Froude opines that Queen Elizabeth was indecisive and a mediocre administrator.

\section{References}

Austin, J.L. (1962). How to Do Things with Words. Oxford: Clarendon Press.

Baker, J.H. (1994) ed. Reports from the Lost Notebooks of Sir James Dyer. Selden Society.

Brooks, Christopher W. (2008). Law, Politics and Society in Early Modern England.Cambridge University Press.

Burke, Kenneth.(1969). A Rhetoric of Motives. Berkeley, Los Angeles, London: University of California Press. Elton, G.R. (1986).The Parliament of England 1559-1581. Cambridge University Press.

Froude, J.A. (1911). The Reign of Elizabeth. Vol 1. J.M.Dent \& Sons, Limited.

Kantorowicz, Ernst H. (1997). The King's Two Bodies: A Study in Mediaeval Political Theology 1957. Princeton, New Jersey: Princeton University Press.

Marcus, Leah. S, Janel Mueller, and Mary Beth Rose (2002) eds. Elizabeth I: Collected Works. Chicago: University of Chicago Press.

Miller, Susan.(1953). Trusts in Texts: A Different History Of Rhetoric. Southern Illinois University Press.

Neale, J.E. . (1953) Queen Elizabeth I and her Parliaments. London.

Orr, D. Alan.(2000). Treason and the State: Law, Politics and Ideology in the English Civil War. Cambridge University Press.

Wilson, Charles.(1970). Queen Elizabeth and the Revolt of the Netherlands. University of California Press.

Nabanita Chakraborty is an Assistant Professor, Department of English, Hansraj College, University of Delhi. Her PhD is on the topic "Rhetoric of Love and Politics of Power: Speeches and Writings of Queen Elizabeth I". She is a recipient of Charles Wallace Fellowship 2012-2013. 